\title{
STUDENTS' UNIONS, CONSUMERISM AND THE NEO-LIBERAL UNIVERSITY
}

\author{
Abstract \\ This article explores the economic relationships between individual students' unions and their \\ wider institutions, and the ways in which they articulate with a pervasive consumerist agenda \\ across the higher education sector. We draw on data from a UK-wide study to argue that \\ students' unions have an ambivalent relationship with consumerist discourses: on the one \\ hand, they often reject the premise that the higher education student is best conceptualised as \\ a consumer, and yet, on the other hand, they frequently accept aspects of consumerism as a \\ means of, for example, trying to protect their independence and autonomy. We explore \\ whether this particular form of positioning with respect to consumerism is best \\ conceptualised as a form of resistance, or whether it has become extremely difficult for \\ students' unions to take up any other position in a system that is driven by market logic.
}

Keywords: students' unions, consumerism, higher education, funding, marketisation

\section{Introduction}

Recent research on students' unions in the UK has suggested that, over the last few years, their role within the higher education (HE) sector and their relationship with their wider institution have both changed considerably (Brooks et al., 2015). Previous work has, however, tended to emphasise the political and organisational aspects of such changes. In this article, we focus more specifically on the economic relationships between individual unions and their wider institutions, and the ways in which they articulate with a widespread 
consumerist agenda within higher education. Although we are cognisant that economic relationships are clearly strongly influenced by the wider political context, we suggest that they provide a useful lens through which to analyse the contemporary workings of the students' union.

In the first part of the article, we situate our research within the extant literature on consumerism and the contemporary university. In particular, we consider arguments about the pervasiveness - but also the messiness - of neo-liberal imperatives, and the extent to which they have affected policies and practices across the higher education sector. We then draw on data from a UK-wide study to argue that students' unions have an ambivalent relationship with consumerist discourses: on the one hand, they often reject the premise that the HE student is best conceptualised as a consumer, and yet, on the other hand, they frequently accept aspects of consumerism as a means of, for example, trying to protect their independence and autonomy. As part of a wider discussion, we explore whether this particular form of positioning with respect to consumerism is best conceptualised as a form of resistance, or whether it has become extremely difficult for students' union officers to take up any other position in a system that is driven by market logic.

\section{Background}

\section{Consumerism and the neo-liberal university}

The shift towards a clear consumerist agenda is often seen as an intrinsic part of the neoliberal university. Neo-liberalism is typically understood as the distinctive political and economic philosophy that first emerged in the 1970s, 'dedicated to the extension of the 
market and market-like forms of governance, rule and control across - tendentially at least all spheres of social life' (Peck and Tickell, 2006, p.28). Thus, within education, academic practice is commodified, business dynamics are introduced as educational services are bought and sold, and 'governance by numbers' becomes increasingly prevalent (Ozga, 2008). Amongst academic staff - within universities as well as the schools sector - performativity is normalised: effort, values, purposes and self-understanding are linked to narrow measures of comparison and output, and staff spend increasing amounts of time reporting on what they do, rather than doing it (Ball, 2012). However, as scholars across the social sciences have noted, there are significant spatial variations in the way neo-liberalism is played out; it is a politically-grounded movement and should thus be conceived, not as an end-state, but a continually realised process (Peck and Tickell, 2006). The messiness and variation of neoliberal practices, with respect to education in particular, have also been highlighted. Indeed, Ball (2012) has defined neo-liberalism as a 'complex, often incoherent, unstable and even contradictory set of practices that are organized around a certain imagination of "the market" as a basis for the universalisation of market-based social relations, with the corresponding penetration in almost every single aspect of our lives' (p.18).

Within this marketised system, in the UK, higher education students are increasingly constructed as consumers. Indeed, the Coalition government's higher education white paper, Students at the Heart of the System (BIS, 2011) set out a series of policies to encourage prospective students to become 'more discerning' (p.29) in their HE choices, including the requirement that all higher education institutions (HEIs) make public, in an accessible format, detailed information about their courses and the employment destinations of their graduates. Furthermore, the radical changes to HE funding in England, outlined in the white paper (namely allowing institutions to charge up to $£ 9000$ per annum in tuition fees from 2012 
onwards) were predicated upon the assumption that prospective students will: see a degree as a private investment (rather than a public good); be prepared to accumulate significant debt in order to acquire it; and actively 'shop around', comparing institutions and courses to secure the 'best' possible education. Although there is evidence that students are sometimes conceptualised in other ways (e.g. Leathwood and Read, 2009), the construction of studentas-consumer is dominant - evident in many other policy pronouncements at the level of both central government and the individual university (Sabri, 2012; Williams, 2013). Such constructions have been embraced by the media, the wider public and senior university managers, as well as by government agencies (Carey, 2013).

The language of consumerism has been particularly prevalent since the fee reforms of 2012 . Nonetheless, this particular understanding of higher education students is not new. Similar assumptions about students as consumers have underpinned HE policy from the early 1990s onwards, as part of a broader reorientation of education along market lines (Scott, 1995). Indeed, for the past two and half decades, 'educational choice' (by prospective students and their families) has been seen by many policymakers from across the political spectrum as a key mechanism for promoting competition between institutions and, consequently, for raising standards. Williams (2013) suggests that this rise in consumerism can be linked, not to the introduction of or increase in fees, but to what she argues has been the redefinition of education over recent decades - as a means to various non-educational ends, such as social inclusion, and an emphasis on 'the student experience'. In developing this argument, she maintains that, as a result of this re-definition, higher education has come to be seen as a right of citizenship, rather than an earned privilege and that this sense of entitlement 'helps enshrine students as consumers' (p.147) irrespective of whether or not they pay fees. 
The construction of student-as-consumer has had particular consequences for those working in HE, and has tended to reduce both the autonomy and control of university staff. As Deem et al. (2007) have argued:

By striving to transform the public service professional into 'the servant of the customer/user' - rather than an autonomous and high status 'technical expert' who controls the process through which user needs are defined, articulated and served $-\ldots$ managerialism [has] progressively reasserted the ideological dominance of an instrumental/market-based rationality and the political dominance of the managerial cadres who operate and police its practical functioning. (p.22)

They go on to contend that university lecturers, like other public service staff, are no longer trusted to 'speak for the consumer' in a context in which market competition has become the main mechanism for resource allocation and distribution. Instead, 'much more powerful governance regimes and intrusive control technologies have to be developed and constructed around the various norms an indicators that stand proxy for "the consumer" of public services' (ibid., pp.22-23). Deem and colleagues maintain that, in this new context of 'consumer empowerment', the dominant values of higher education have shifted away from professionalism and elitism towards an overriding concern with consumerism and populism.

\section{Neo-liberal hearts and minds?}

Extant literature on the contemporary university has demonstrated effectively the ways in which neo-liberalism affects our hearts and minds, and the social relationships we form, not only the political and economic structures within which we work: 'It is about how we relate 
to our students and our colleagues and our participation in new courses and forms of pedagogy and our "knowledge production", but it is also about our flexibility, malleability, innovation and productivity in relation to these things' (Ball, 2012, p.18). The repositioning of universities as servants of the knowledge economy, and students as consumers, has been associated, Brady (2012) argues, with a sense of 'moral loss' within the higher education sector, "with much human interaction in academic reduced to the banality of transactional exchange' (p.244). Molesworth et al. (2009) contend that the inculcation of a consumer identity has brought about a more passive approach to learning, in which students place much more emphasis on their rights rather than their responsibilities, and on having a degree rather than being a learner, while empirical research has demonstrated the ways in which relationships between students within the classroom are often inflected with the values of competition and individualism (Brooks, 2007). Moreover, recent research has also pointed to the influence of neo-liberalism in spaces beyond the classroom. For example, Phipps and Young (2014) have argued that the growth of 'lad cultures' in UK universities is inextricably linked to the wider neo-liberal-informed norms that now pervade higher education institutions. In developing this argument, they contend that a market-based rationality is now dominant in all spheres of university life, in which competitive individualism is situated as 'the central attribute for a citizenry of constantly reinventing entrepreneurs' (p.9), and students' lives become directed towards self-interest and acquisition. They go on to maintain that such dispositions are not confined to students' approaches to learning, but are played out in relations with other students and in the sexual sphere. Thus, while sexual violence is not new, 'the neoliberal university provides an environment in which it can both flourish and be normalised' (p.12). In this analysis (and that pursued by many other sociologists (Skeggs, 2014)), it is suggested that, as we internalise the norms of capitalism and pursue self-interest and future accrual, our subjectivity changes to fit the logic of neo-liberalism. 
Others have, however, argued that, despite the increasing recourse to the language of economics in policy documents (in which students are positioned as consumers and universities as providers), in practice, the behaviour of prospective students does not conform to this model. Dodds (2011, p.321) argues that students are not simply 'consumers'; they also constitute important 'inputs in the production process', given that the experience of one student is inevitably influenced by the identifications and meaning-making of the other students who are recruited onto the same course. Similarly, Nordensvärd (2011) suggests that even within a neo-liberal consumer framework, students are required to assume roles beyond that of the consumer - as a 'manager' of their own life, future and CV, and as a 'commodity', which is both invested in and managed by the state - while Williams (2013) has argued that 'for the most part, students do not want to be considered as consumers, and lecturers do not want to deliver a service' (p.148). Furthermore, there is compelling evidence to suggest that students do not act as the rational economic actors assumed by most policy texts. Research has shown, for example, that there is no simple relationship between the provision of information about HE and the knowledge acquired by prospective students (Dodds, 2011): 'official' information from universities is often mediated by a range of social factors (Brooks, 2003; Reay et al., 2005). Others have suggested that it is only more affluent groups who have the capacity to 'shop around', unencumbered by financial concerns or the 'identity risks' of moving away from home (Patinotis and Holdsworth, 2005). Such arguments accord with the wider literature on English educational policy, which indicates that policy pronouncements are rarely straightforwardly transferred into practice. Instead, they are 'enacted' by relevant actors who interpret, translate and sometimes resist policy imperatives (Ball et al., 2011).

The remainder of this article draws on data from students' union leaders to explore the ways in which consumerist agendas are played out. While clearly the students' union constitutes 
only a relatively small part of the contemporary university, within the UK it has become an increasingly important one. Unions have assumed high profile roles within HE governance (as engaging with the students' union is also often seen as an effective means of gauging the views of the student body as a whole) while, in a higher education sector in which more emphasis has come to be placed on 'the student experience' rather than just the process of teaching and learning, students' unions are often seen as important partners in the delivery of these wider aspects of university life (Sabri, 2012).

\section{Research methods}

The data drawn upon in this article were collected as part of a project that explored the changing nature of student leadership in the UK. Although the broader project included an online survey and focus groups with specific role-holders within students' unions (e.g. presidents, education officers), in this article we draw primarily on the data collected from 20 focus groups in ten HEIs. The ten HEIs were chosen to represent the diversity of the HE sector (as well as different patterns of response to the online survey) and comprised: three HEIs in the Russell Groupi; two HEIs established in the 1960s, that are not part of the Russell Group; four newer institutions that gained university status after 1992; and one specialist HEI that offers a relatively limited range of courses. In each institution, two focus groups were conducted: one with students' union officers (typically comprising four to six individuals) ${ }^{\mathrm{ii}}$, and a second with senior managers (typically comprising four individuals). In total, 88 people took part in one of the 20 focus groups: 42 senior managers and 46 students' union officers. With the agreement of participants, the focus groups were audio-recorded and fully transcribed, and the transcriptions uploaded to NVivo, a software package for qualitative data 
analysis. The transcripts were then analysed, and themes identified. We also draw on an analysis of policy documents produced by the National Union of Students.

Although the impact of consumerist agendas was not asked about directly during the focus groups, it was an important theme in many of them, typically raised in relation to questions about the perceived effectiveness and impact of the students' union, and the nature of the relationship between the students' union and the wider university ${ }^{\text {iii }}$. In the context of the discussion below, it is important to note that, within the UK, students' unions are funded through an annual 'block grant' from their higher education institution. In some institutions, this is supplemented with income derived from commercial activities such as shops, bars and nightclubs - although, across the sector, the revenue from such sources has declined significantly over the past two decades (Bols, 2014).

\section{Students' unions and consumerism: a complex relationship}

The UK's National Union of Students has offered an explicit challenge to some of the assumptions upon which, they argue, consumerism is based, through an emphasis on 'partnership working' with senior institutional managers. This has been articulated as part of an attempt to develop an alternative political agenda, with student leaders conceived of as coproducers within institutional governance. This approach is outlined in some detail within the document Manifesto for Partnership, published by the NUS in 2012. The manifesto argues that partnership between students and university leaders 'holds out a space for political resistance and organisational change, not least in resisting the burgeoning signs of a damaging market in education' (NUS, 2012, p.2), and provides a strong critique of the consumerist model of higher education: 
...students as partners offers a valuable alternative to the rhetoric of consumerism. Regardless of whether students agree with the values and characteristics of the funding model in which they sit, they may adopt behaviours we associate with consumerism unless we offer a new and compelling way of thinking about learning. In the absence of policy changes, our shared challenge as a sector is to do our best to eclipse the effects of a consumerist model. By developing new practice and challenging behaviours, we can protect and grow the extent to which students are given the opportunity to experience the transformational effects of higher education. (ibid., p.6)

In his typology of the various cases made to justify student representation within universities, Luescher-Mamashela (2013) identifies what he argues are the four most prevalent, i.e. politically-realist, consumerist, communitarian and democratic cases. The language of partnership used in the document cited above, and by members of students' unions when advocating co-production, draws strongly on the communitarian case. From this perspective, students' claims to involvement in university decision-making are premised on their status as 'members of a collectivity engaged in the educational process' (Luescher-Mamashela, 2013, p.1449), and thus not on their rights as 'consumers' or indeed as representatives of other consumers.

This rejection of consumerism was evident in the focus group discussions, when students' union officers discussed the commercial ventures with which their wider university was engaged. Many argued that HEIs had become increasingly focussed on the generation of profit and, in some cases, had lost sight of what they perceived to be the real purpose of 
higher education. The following quotations from two of our case study institutions are indicative:

And they say that they are for students but they, I feel that they're for conferencing [i.e. they prioritise conference-related activity]. I've heard on more than one occasion, the narrative scares me more than anything else, I hear the university talking about them as a business and I understand there has to be an element of business within the universities, they have to consider that they don't run out of money next year, but this university is not running out of money any time soon. And .... they don't consider themselves a charity any more, they consider themselves a business. (Students' union focus group, HEI 4)

the conferencing, yes, can be important at times but that shouldn't be the main goal ..... the main goal shouldn't really be kind of profit margins at the end of the day, it should be about students. (Students' union focus group, HEI 10)

As we have argued elsewhere (Brooks et al., 2015), there is some evidence from our research that students' unions and senior managers believed the values of the two groups were becoming increasingly aligned, largely as a result of external pressures within the HE sector. For example, the introduction of a question, specifically about the performance of the students' union, within the National Student Survey ${ }^{\text {iv }}$, has provided a measure through which unions are now publicly judged and nationally ranked. While such a change could be viewed as licence for students' unions to be more vociferous in pushing student concerns - as a means of securing the approval of the wider student population - our data suggest that it has had the opposite effect, and increased the performative pressures on unions and, perhaps as a 
result, their alignment with senior management agendas (ibid.). Nevertheless, within some institutions, clear dissonance was apparent - and particularly in relation to the extent to which HEIs should be pursuing a profit- and consumer-oriented agenda. Indeed, focus group participants at HEI 6 believed that, as a result of their HEI's increasing consumer focus, the students' unions had come to occupy a more marginal role within the institution: 'Universities across the board have gone a lot more corporate and I think when they try and go corporate and try and maintain this corporate face, forward facing front, the unions are looked at as you know just complementary to everything else that's going on'. Data such as these emphasise strongly the antipathy felt, in some students' unions, towards what they believed to be an encroaching consumerist agenda and its embrace by senior institutional managers.

Nevertheless, despite the strongly worded rejection of consumerism in the NUS' Manifesto for Partnership, and the criticism of senior managers, on the part of some students' unions, for embracing too fully a business-oriented agenda, the position of many unions with respect to consumerism was complex, and at times seemingly contradictory. Indeed, it appeared that consumerism was sometimes pursued as a means of increasing the unions' independence and strengthening its ability to take forward its own agenda, which often had a deleterious impact on partnership-working within the wider institution.

Three of the unions in our sample of ten believed strongly that the profit derived from their commercial ventures (such as running campus bars and shops) was very important in helping to protect their independence, and gave then some autonomy in deciding how to spend their money. This was associated with a view that, if their sole source of funding was the block grant, they would be expected to align their activities closely with the priorities of their HEI. 
In this kind of situation, the generation of profit was viewed in far more positive terms than when it was being generated by the university. As the students' union focus group at HEI 5 claimed, 'In terms of effectiveness....we make a lot of money, which is why we're able to do so much stuff, because like the student nightclub makes a profit which not many student unions can boast'. Senior managers also recognised that a source of income separate from the block grant was valued by unions and, without it, they were likely to become much more dependent on the institution:

I think, yeah, it's fair to say, sometimes student unions ... fear they might lose some of their autonomy if they didn't have their own commercial arm to generate income and so on, those sorts of things. (Senior managers focus group, HEI 8)

So now they've largely moved away from running bars, there's no bar, or no permanent bar certainly on this campus.... I mean the weakness I think is the overdependence that they feel they have on the university, they don't have independent means of generating income...It's more a weakness from their point of view I think than from our point of view. (Senior managers focus group, HEI 9)

Many of the unions without additional income derived from commercial services (and some of those that did secure money in this way) believed that funding their activities through this means made it difficult to do anything other than follow the agenda set by the wider university. For example, at HEI 7, the students' union no longer ran any commercial services of its own. Focus group participants described how the union and university had had a major disagreement over the provision of sports facilities within the institution: the union wanted to 
provide more in this area but, as the university refused to provide additional funding and the union had no unallocated income of its own, it was unable to pursue this agenda.

Overall, six of the ten students' unions in our sample operated some kind of commercial activity. The most common activities were running shops and bars, but some unions also ran nightclubs and/or student accommodation. As suggested above, much of this activity was valued by union officers because of the additional income it generated, which typically reduced dependency on the block grant and allowed unions a greater degree of freedom to pursue their own initiatives. Nevertheless, in some institutions, this type of commercial focus was not always welcomed by institutional managers and, in some cases, was thought to have had a negative impact on partnership working. Firstly, some senior managers believed that commercial ventures were a distraction from more important functions that students' unions should be carrying out, such as representation:

I think going forward, the question may well be is, is it right that the student union actually do run commercial activities? Or is it better that the university should manage those along with other things, you know. And I think that's probably a conversation that will happen over the next few years, to what extent we should just let the students look at the student affairs rather than worry about stocking the shop and that sort of thing. So that's an area where there may well be further change going forward. (Senior managers focus group, HEI 8)

Secondly, both institutional managers and students' union officers recognised that often there was direct competition on campus between the services offered by the union and those run by the university: 
And one of the tensions that the university has, ... is because I'm responsible for the university's commercial services, we're actually in competition with [the union], which I wouldn't necessarily see as healthy, it would be healthy if it was good for the customer, because competition normally is, but what actually happens is that we end up, on one hand collaborating with them on many ventures and in others competing head to head. And it's very difficult to understand where the lines are drawn on that because it's deeply blurred. (Senior managers, HE1 4)

In some institutions, senior managers' concern about students' unions pursuing commercial ventures was related to broader concerns about union officials' competence in dealing with financial matters. This was a recurrent theme in five of the ten case study institutions, mentioned by participants in the students' union focus group, as well as that comprised of senior managers. For example, at HEI 3, the students' union focus group described how, almost a decade ago, 'the commercial stuff dived, the university had to step in and bail us out a couple of times' and how this had undermined senior managers' trust in the union, and continued to affect current relationships: 'So I can see why they distrust us but they are reluctant to move on from that idea, even though demonstrably we've shown that we can do it'. Similarly, senior managers at HEI 9 described how past financial mismanagement on the part of the union had had a long legacy:

I guess the most difficult thing is around the issue they got themselves into five year ago financially, which required the university to bail them out. So we've kept quite a close monitoring role on their financial position over the last few years. I guess that's beginning to go ... a little more distant now because they have, coming back to the issue of competence, they have demonstrated a large degree of competence in actually 
enabling, you know, keeping their books in balance, although we do still keep an eye on it. (Senior managers' focus group, HEI 9)

Distrust of this nature, over perceived financial competence, has been identified in other studies (Rodgers et al., 2011), and it is likely that it is heightened in instances where one side believes that the other has encroached into its territory - in terms of the provision of students' services and commercial activities. Historically, a significant number of unions have had to be rescued financially by their HEI (ibid.), and this experience within the sector as a whole may well also have a bearing on the attitudes and dispositions of senior managers even in institutions in which the students' union has not run into such difficulties.

Data from the study also indicate that some students' unions had, over time, changed their position on consumerism such that they were now prepared to use the language of the consumer to advance their own agenda. The students' union focus group at HEI 1 articulated this shift clearly:

That new level of willingness [on the part of institutional management] to engage with student leadership .... is at least partly financially motivated because they know they've got to respond to the customers as it were. When people started talking about students as customers a few years ago we were, you know, we wouldn't have anything to do with it but I think it actually suits us now to put them in that place sometimes in front of the university because you know they understand the concept of customer service whereas ...Mm, customer's always right. 
This data, in common with that discussed previously in this section, indicate that, despite a seeming opposition to consumerist discourses and policies (particularly when promoted by government and/or senior university management), students' unions were willing to undertake consumer-focussed activities themselves when they were believed to serve some wider goal (for example, helping to protect the independence of the union). Nevertheless, while such activities were often justified on the basis of protecting unions from increasing encroachment on the part of the HEI and an obligation to conform to its agenda, they often have had the effect of undermining partnership working - and thus, as argued above, an important strand of the student movement's rejection of consumerist policies.

\section{Discussion}

\section{$\underline{\text { Inconsistencies and entanglements }}$}

Our data provide clear evidence to indicate that, just as neo-liberalism can be considered an inconsistent and incoherent set of practices (Ball, 2012), so too can responses to it. The narratives generated by our focus groups with students' union officers and senior institutional managers, suggest strongly that there is a high degree of ambivalence in union officers' attitudes to and engagement with consumerism - a key part of the neo-liberal agenda. On the one hand, many of those we spoke to endorsed (implicitly or explicitly) the renouncement of consumerist logic as articulated by the NUS' (2012) Manifesto for Partnership - in relation to the values of the higher education sector generally and their HEI more specifically. As we have noted above, this often included a specific criticism of senior institutional managers for pursuing a business agenda, and attempting to maximise profit through conferences and other commercial ventures. Such activities were thought to be inimical to a prioritising of student 
concerns. However, on the other hand, there was clear evidence - outlined above - that many unions were also willing to embrace a consumer identity themselves, in part as an attempt to reduce their dependence on the wider HEI. Such ambivalence has been identified in other parts of the higher education sector. For example, in her analysis of the relationship between consumerism and funding mechanisms with higher education, Williams (2013) has argued that government documents themselves contain contradictory constructions of students. She suggests that while, in many places, the higher education white paper, Students at the Heart of the System (BIS, 2011), conceptualises students as rational actors within a free education market (a dominant construction articulated by politicians and policymakers), in other places they are understood as vulnerable in the face of the market, necessitating the intervention of government to protect their interests and act as arbitrator - by, for example, requiring institutions to produce 'key information sets'.

One reading of the narratives of our respondents is that they are merely part of the inconsistencies inherent in neo-liberal practices (Ball, 2012), and should not be seen as anything other than part of the 'lumpy' way in which consumerism, marketisation and other neo-liberal forms of engagement infuse and become entangled with everyday activities. However, this assumes that students and other actors are not themselves genuinely able to hold any 'values beyond value' (Skeggs, 2014) within the contemporary university, nor able to mount any effective opposition to consumerist practices. Our discussion now considers both these points in turn. 


\section{$\underline{\text { Hearts, minds and 'values beyond value' }}$}

As noted in the first part of this article, neo-liberalism has been argued not merely to constitute a specific set of market-based political and economic arrangements, but to affect our subjectivity as well, i.e. as Ball (2012) puts it, being 'in here' as well as 'out there' (see also Phipps and Young, 2014). Nevertheless, the data from the study indicate that, despite evidence that much of higher education in the UK is now based on market logic, the minds of those involved in our research had not necessarily been taken over by neoliberalism. Although, as we have shown, some of our respondents accepted market mechanisms if they helped to promote the role of the union, alongside this activity, they had a desire to pursue partnership working as an alternative to consumerism, and were critical of their HEI's focus on profit-generating pursuits. Thus, while students' unions appeared relatively powerless to change the wider political and economic structures around them, they were apparently able to resist the extent to which neoliberalism 'gets into our minds and our souls, into the ways in which we think about what we do, and into our social relations with others' (Ball, 2012, p.18). Clearly there are some inconsistencies and ambiguities in the position adopted by many of our respondents, as discussed above. Nonetheless, we would suggest that in the explicit critique of consumerism and profit-making activity advanced by some students' union officers - if not in the specific actions they pursued - there is some evidence of a counter-discourse, and of students holding values beyond the narrowly economic and transactional.

Here there is resonance with the work of Skeggs (2014), who has argued that in her research, conducted over decades with 'those designated as improper' (p.16), such as working-class women, a range of values - generated in opposition to the values of capital - were practised 
and expressed by her respondents, including caring, anti-greed, anti-instrumentalism and an opposition to injustice. Skeggs contends that respondents such as hers are affected less by neo-liberal imperatives because of the ways in which they are excluded by mainstream society: 'Capital's call to neo-liberal governmentality is not easily heard by those who are excluded from and exist to mark the limit [of] proper personhood, who have no access to the resources to become capital's subjects of value' (p.15-16). While university students clearly do not fall into the same category - indeed, some may argue they are the archetypal 'subjects of value' - our data suggest that there are some spaces within higher education which have not been completely colonised by capital, and in which students can provide mutual support to one another in developing alternative values. Recent research on student societies, for example, has argued that they can constitute important loci for young people to develop their political habitus and for the development and performance of the political self (Crossley, 2008; Loader et al., 2014). While there is certainly evidence that university campuses can be experienced as exclusionary spaces by some groups (e.g. Andersson et al., 2012; Hopkins, 2011), the narratives of our respondents suggest that university can also constitute, as Naidoo (2003) has argued, 'a crucial mediating context through which they forces associated with commodification may be displaced, restructured or even subverted' (p.255). We would thus agree with Skeggs (2014) that living with the logic of capital does not mean that we necessarily internalise these values; while students may ultimately be subject to the imperatives of neo-liberalism and the realism of the higher education market, they are not the only social relations that shape them. 


\section{The nature of critique}

The evidence from our study suggests that while the logic of the market does not necessarily determine the values of students, including those who occupy leadership positions in students' unions, it does have a significant impact on the extent to which they are able to pursue activities that act in opposition to consumerist agendas. Indeed, despite articulating a critique of profit-making activity and the construction of the higher education student as a consumer, our respondents were ultimately able to effect little change in their institutions. Moreover, because of the consumer-based structures that underpinned much of their activity, they sometimes ended up embracing consumerism as a means of achieving other goals (for example, in relation to furthering union independence and autonomy). A similar disconnect is noted by Brady (2012) in his analysis of broader discourses about contemporary higher education in the UK. He argues that while there is evidence of various discourses that provide a challenge to neo-liberal hegemony (for example, those that focus on: the cultivation of 'academic citizenship'; the re-emergence of a critical voice amongst staff and students; and restorative qualities of teaching and learning practice), by themselves they are unlikely to bring about the conditions necessary for a radical change of direction in UK higher education policy. He concludes that 'perhaps the best hope for the moral reconstruction of UK universities lies in the spectacular "unravelling" in recent years of neoliberal policies and narratives' (p.353).

Sukareih and Tannock (2015) have taken a rather different position in their analysis of recent challenges to higher education reform across the globe. They note that, since 2009 , fifty countries have witnessed student protests - including the UK, US, Canada and Chile, in which they have been particularly strong. These protests shared a common set of concerns, 
namely opposition to increases in tuition fees and student loan debt, cuts to public funding and the privatisation of post-secondary education. Such concerns are clearly related to the dominance of a neo-liberal agenda and associated assumptions that welfare costs should be shifted away from the state to individuals and the private sector, which have been exacerbated in some parts of the world by austerity policies introduced in response to the global financial crisis. Sukareih and Tannock argue that these protests were underpinned by a fundamentally conservative agenda, which did not challenge the basic tenets of neoliberalism. Indeed, they contend that by focussing on preserving and defending current systems from proposed future restructuring they failed to address 'the underlying contradiction that providing universal access to post-secondary education in the pursuit of social and economic mobility cannot and will not provide social and economic mobility (or even security) for everyone in a deeply unequal capitalist society and economy' (p.127). In their analysis, the student protests of the $21^{\text {st }}$ century should not be understood as a radical rejection of the contemporary model of higher education but, instead, its ultimate realisation.

The data we report in this paper can also be seen as evidence of conservatism on the part of students' unions - being willing to go along with various consumerist practices, while also critiquing them. However, it is also important to recognise the significant limits on student action imposed by the system in which they are operating. The impact of the wider political and economic context is highlighted by Klemenčič (2014) in her cross-national comparison of protests by students' unions. She argues that such protests had most impact in countries in which neo-liberal norms were less strong, as governments were reluctant to push through radical reform if they believed such policies would not win widespread cultural acceptance. In the UK, for example, she contends that student protests had little impact on government policymaking with respect to fees because of the government's calculation that there was 
sufficient support in society more generally for its fees policy and broader consumerist agenda. In countries such as Chile and Canada, however, the obstruction of policy by students' unions was more successful because, Klemenčič argues, it was more in line with the views of other social actors, who had a less strong commitment to neo-liberal norms than their counterparts in the UK. While the data we discuss in this paper is not about protest, it is about the adoption of particular political positions, and thus paying attention to the constraining effects of wider political structures remains important.

\section{Conclusion}

In her analysis of changes within Australian higher education, Rochford (2014) argues that:

The student organisation occupies difficult terrain, simultaneously acting as a service provider, student advocate and political lobbyist. Just as the university has to ensure congruence with government policy but remain impartial, student organisations occupy a politicised realm within an apparently neutral market framework. (p.486)

In this article, we have suggested that the terrain occupied by UK students' unions is equally difficult. In particular, we have argued that in a context in which the student is understood as a consumer by politicians, policymakers and other social actors, it is hard for students' unions to resist this dominant policy discourse, even if they want to. More specifically, we have presented evidence from our national study of UK students' unions to suggest that many students' unions, and the individual officers who make them up, have an ambivalent relationship with consumerism. Echoing the language used within documents produced by the NUS, many unions articulated a clear opposition to consumerism, when pursued by 
government and their own HEIs, and often advocated 'partnership-working' as a means to advance an alternative agenda. Nevertheless, our data also show that, in many cases, unions place considerable importance on their own consumer activities. One interpretation of this emphasis on commercial ventures is that it is a form of resistance - a means of ensuring an independent income in a climate in which there are increasing pressures to conform to the agenda of the wider institution. However, we have also indicated that, in many cases, such commercial activities had the unanticipated consequence of undermining partnerships primarily because of the competition that was often created within the HEI.

It is perhaps ironic that, for students' unions, one of the main means of retaining independence (and thus being able to resist some of the imperatives of HEIs that are often driven by consumerist agendas) is embracing commercialism and providing services to paying students. However, our research is important in documenting some of the real tensions experienced by those who wish to reject consumerism, and the limited impact a document like the NUS' Manifesto for Partnership is likely to have when both unions and HEIs are embedded within a system premised on market logic. In documenting these tensions, our research has underlined the importance of paying attention to the inconsistencies and ambiguities that make up the practices of the neo-liberal university. It has also emphasised that, although in their practical actions students' unions have been able to offer little resistance to dominant neo-liberal agendas, this does not mean that the subjectivities of students are necessarily aligned with the norms of capitalism, consumerism and marketisation. Indeed, drawing on Skeggs' work, we have shown how many of our respondents held 'values beyond value', and beliefs that were in opposition to the prevalent consumerist agenda. This perhaps provides a useful point of departure for a process of 'moral reconstruction' (Brady, 2012) within the higher education sector. 


\section{Acknowledgements}

We are very grateful to all the people who gave up their time to be involved in the research through completing the survey and/or taking part in a focus group. We would also like to thank the National Union of Students and the Leadership Foundation for Higher Education for funding the project, and the very helpful comments on a previous version of this paper from two anonymous referees. All opinions expressed above are, however, our own.

\section{References}

Andersson, J., Sadgrove, J. and Valentine, G. (2012) Consuming campus: geographies of encounter at a British university, Social and Cultural Geography, 13, 5, 501-515.

Ball, S. (2012) Performativity, commodification and commitment: an I-Spy guide to the neoliberal university, British Journal of Educational Studies, 60, 1, 17-28.

Ball, S., Maguire, M., Braun, A. and Hoskins, K. (2011) Policy actors: doing policy work in schools, Discourse: Studies in the Cultural Politics of Education, 32, 4, 625-639.

Bols, A. (2014) The 1994 Education Act and Students' Unions Available at: http://www.wonkhe.com/2014/06/26/the-1994-education-act-and-students-unions/ (Accessed 17/07/14). 
Brady, N. (2012) From 'moral loss' to ‘moral reconstruction'? A critique of ethical perspectives on challenging the neoliberal hegemony in UK universities in the $21^{\text {st }}$ century, Oxford Review of Education, 38, 3, 343-355.

Brooks, R. (2003) Young people's higher education choices: the role of family and friends, British Journal of Sociology of Education, 24, 3, 283-297.

Brooks, R. (2007) Friends, peers and higher education, British Journal of Sociology of Education 28, 6, 693-707.

Brooks, R., Byford, K. and Sela, K. (2015) The changing role of students' unions within contemporary higher education, Journal of Education Policy, 30, 2, 165-181.

Brooks, R., Byford, K. and Sela, K. (forthcoming) Inequalities in students' union leadership: the role of social networks, Journal of Youth Studies.

Carey, P. (2013) Student engagement: stakeholder perspectives on course representation in university governance, Studies in Higher Education, 38, 9, 1290-1304.

Crossley, N. (2008) Social networks and student activism: on the politicising effect of campus connections, The Sociological Review, 56, 1, 18-38.

Deem, R., Hillyard, S. and Reed, M. (2008) Knowledge, Higher Education, and the New Managerialism: The Changing Management of UK Universities Oxford, Oxford University Press. 
Department for Business, Innovation and Skills (BIS) (2011) Students at the Heart of the System Cm. 8122 London, The Stationery Office.

Dodds, A. (2011) The British Higher Education Funding Debate: the perils of 'talking economics', London Review of Education, 9, 3, 317-331.

Hopkins, P. (2011) Towards critical geographies of the university campus: understanding the contest experiences of Muslim students, Transactions of the Institute of British Geographers, $36,157-169$.

Klemenčič, M. (2014) Student power in a global perspective and contemporary trends in student organising, Studies in Higher Education, 39, 3, 396-411.

Leathwood, C. and Read, B. (2009) Gender and the Changing Face of Higher Education, Buckingham, Open University Press and SRHE.

Loader, B., Vromen, A., Xenos, M., Steel, H. and Burgum, S. (2014) Campus politics, student societies and social media, The Sociological Review. (Advance online access)

Luescher-Mamashela, T. (2013) Student representation in university decision-making: good reasons, a new lens? Studies in Higher Education, 38, 10, 1442-1456. 
Molesworth, M., Nixon, E. and Scullion, E. (2009) Having, being and higher education: the marketization of the university and the transformation of the student into consumer, Teaching in Higher Education, 14, 3, 277-287.

Naidoo, R. (2003) Repositioning higher education as a global commodity: opportunities and challenges for future sociology of education work, British Journal of Sociology of Education, $24,2,249-259$.

National Union of Students (2012) Manifesto for Partnership London, NUS.

Nordensvärd, J. (2011) The consumer metaphor versus the citizen metaphor: different sets of roles for students, in: Molesworth, M., Scullion, R. and Nixon, E. (eds) The Marketisation of Higher Education and the Student as Consumer London, Routledge.

Ozga, J. (2008) Governing knowledge: research steering and research quality, European Educational Research Journal, 7, 3, 261-272.

Patinoitis, J. and Holsworth, C. (2005) 'Seize that chance!' leaving home and transitions to higher education, Journal of Youth Studies, 8, 81-95.

Peck, J. and Tickell, A. (2006) Conceptualising Neoliberalism, Thinking Thatcherism, in: Leitner, H., Peck, J. and Sheppard, E. (eds) Contesting Neoliberalism: Urban Frontiers New York, Guilford Press, pp. 26-50. 
Phipps, A. and Young, I. (2014) Neoliberalisations and 'lad cultures' in higher education, Sociology (Advance online access).

Reay, D., David, M. and Ball, S. (2005) Degrees of Choice: social class, race and gender in higher education Stoke-on-Trent, Trentham Books.

Rodgers, T, Freeman, R., Williams, J. and Kane, D. (2011) Students and the governance of higher education: a UK perspective, Tertiary Education and Management, 17, 3, 247-260.

Rochford, F. (2014) Bringing them into the tent - student association and the neutered academy, Studies in Higher Education, 39, 3, 485-499.

Sabri, D. (2012) What's wrong with the 'student experience'? Discourse: Studies in the Cultural Politics of Education, 32, 5, 657-676.

Scott, P. (1995) The Meanings of Mass Higher Education Buckingham, Open University Press and the Society for Research into Higher Education.

Skeggs, B. (2014) Values beyond value? Is anything beyond the logic of capital? British Journal of Sociology, 65, 1, 1-20.

Sukarieh, M. and Tannock, S. (2015) Youth Rising? The Politics of Youth in the Global Economy New York, Routledge. 
Williams, J. (2013) Consuming Higher Education. Why Learning Can't Be Bought, London,

Bloomsbury.

\footnotetext{
i The Russell Group is comprised of 24 'research intensive' HEIs, which typically occupy high positions in national league tables.

ii For a discussion about the social characteristics of students' unions leaders (such as gender, ethnicity, age and sexuality) and the extent to which these students can be considered representative of the wider student body, please see Brooks et al. (forthcoming).

iii Because data were collected at the level of the group (through focus groups, and questions about the students' union as a whole), it is not possible for us to discuss how individuals may have been positioned differently in relation to consumerist agendas by virtue of the social characteristics. We do, however, acknowledge that previous research has documented that not all students are affected in the same way by neo-liberal imperatives. ${ }^{\text {iv }}$ Since 2005, the National Student Survey (a survey that all final year undergraduates across the UK are asked to complete) has asked students about the extent to which they agree that 'I am satisfied with the Students' Union at my institution'.
} 